\title{
Methods to assess iron and iodine status
}

\author{
Michael B. Zimmermann ${ }^{1,2 *}$ \\ ${ }^{1}$ Laboratory for Human Nutrition, Swiss Federal Institute of Technology, Schmelzbergstrasse 7, LFV E 19, CH-8092 Zürich, \\ Switzerland \\ ${ }^{2}$ The Division of Human Nutrition, Wageningen University, Wageningen, The Netherlands
}

Four methods are recommended for assessment of iodine nutrition: urinary iodine concentration, the goitre rate, and blood concentrations of thyroid stimulating hormone and thyroglobulin. These indicators are complementary, in that urinary iodine is a sensitive indicator of recent iodine intake (days) and thyroglobulin shows an intermediate response (weeks to months), whereas changes in the goitre rate reflect long-term iodine nutrition (months to years). Spot urinary iodine concentrations are highly variable from day-to-day and should not be used to classify iodine status of individuals. International reference criteria for thyroid volume in children have recently been published and can be used for identifying even small goitres using thyroid ultrasound. Recent development of a dried blood spot thyroglobulin assay makes sample collection practical even in remote areas. Thyroid stimulating hormone is a useful indicator of iodine nutrition in the newborn, but not in other age groups. For assessing iron status, haemoglobin measurement alone has low specificity and sensitivity. Serum ferritin remains the best indicator of iron stores in the absence of inflammation. Measures of iron-deficient erythropoiesis include transferrin iron saturation and erythrocyte zinc protoporphyrin, but these often do not distinguish anaemia due to iron deficiency from the anaemia of chronic disease. The serum transferrin receptor is useful in this setting, but the assay requires standardization. In the absence of inflammation, a sensitive method to assess iron status is to combine the use of serum ferritin as a measure of iron stores and the serum transferrin receptor as a measure of tissue iron deficiency.

Iodine: Iron: Status: Assessment: Deficiency: Review

\section{Iodine}

Four methods are generally recommended for assessment of iodine nutrition in populations: urinary iodine concentration (UI), the goitre rate, serum thyroid stimulating hormone (TSH), and serum thyroglobulin (Tg) (Tables 1 and 2). These indicators are complementary, in that UI is a sensitive indicator of recent iodine intake (days) and $\mathrm{Tg}$ shows an intermediate response (weeks to months), whereas changes in the goitre rate reflect long-term iodine nutrition (months to years).

\section{Thyroid size}

Two methods are available for measuring goitre: neck inspection and palpation, and thyroid ultrasonography. By palpation, a thyroid is considered goitrous when each lateral lobe has a volume greater than the terminal phalanx of the thumbs of the subject being examined. In the classification system of $\mathrm{WHO}^{(1)}$, grade 0 is defined as a thyroid that is not palpable or visible, grade 1 is a goitre that is palpable but not visible when the neck is in the normal position (i.e., the thyroid is not visibly enlarged), and grade 2 goitre is a thyroid that is clearly visible when the neck is in a normal position. Goitre surveys are usually done in school age children.

However, palpation of goitre in areas of mild iodine deficiency has poor sensitivity and specificity; in such areas, measurement of thyroid volume (Tvol) by ultrasound is preferable ${ }^{(2)}$. Thyroid ultrasound is non-invasive, quickly done
(2-3 min per subject) and feasible even in remote areas using portable equipment. However, interpretation of Tvol data requires valid references from iodine-sufficient children. In a recent multicentre study, Tvol was measured in 6-12y-old children $(n=3529)$ living in areas of long-term iodine sufficiency on five continents. Age- and body surface area- specific 97th percentiles for Tvol were calculated for boys and girls ${ }^{(3)}$. Goitre can be classified according to these international reference criteria, but they are only applicable if Tvol is determined by a standard method ${ }^{(3,4)}$. Thyroid ultrasound is subjective and requires judgement and experience. Differences in technique can produce interobserver errors in Tvol as high as $26 \%{ }^{(5)}$.

In areas of endemic goitre, although thyroid size predictably decreases in response to increases in iodine intake, thyroid size may not return to normal for months or years after correction of iodine deficiency ${ }^{(6,7)}$. During this transition period, the goitre rate is difficult to interpret, because it reflects both a population's history of iodine nutrition and its present status. Aghini-Lombardi et al. ${ }^{(6)}$ suggested that enlarged thyroids in children who were iodine deficient during the first years of life may not regress completely after introduction of salt iodization. If true, this suggests that to achieve a goitre rate $<5 \%$ in children may require that they grow up under conditions of iodine sufficiency. A sustained salt iodization program will decrease the goitre rate by ultrasound to $<5 \%$ in school-age children and this indicates disappearance of iodine deficiency as a significant public health problem ${ }^{(1)}$. WHO recommends the total goitre rate be used to define 
Table 1. Epidemiological criteria for assessing iodine nutrition in a population based on median and/or range of urinary iodine concentrations (WHO/UNICEF/ICCIDD, 2007)

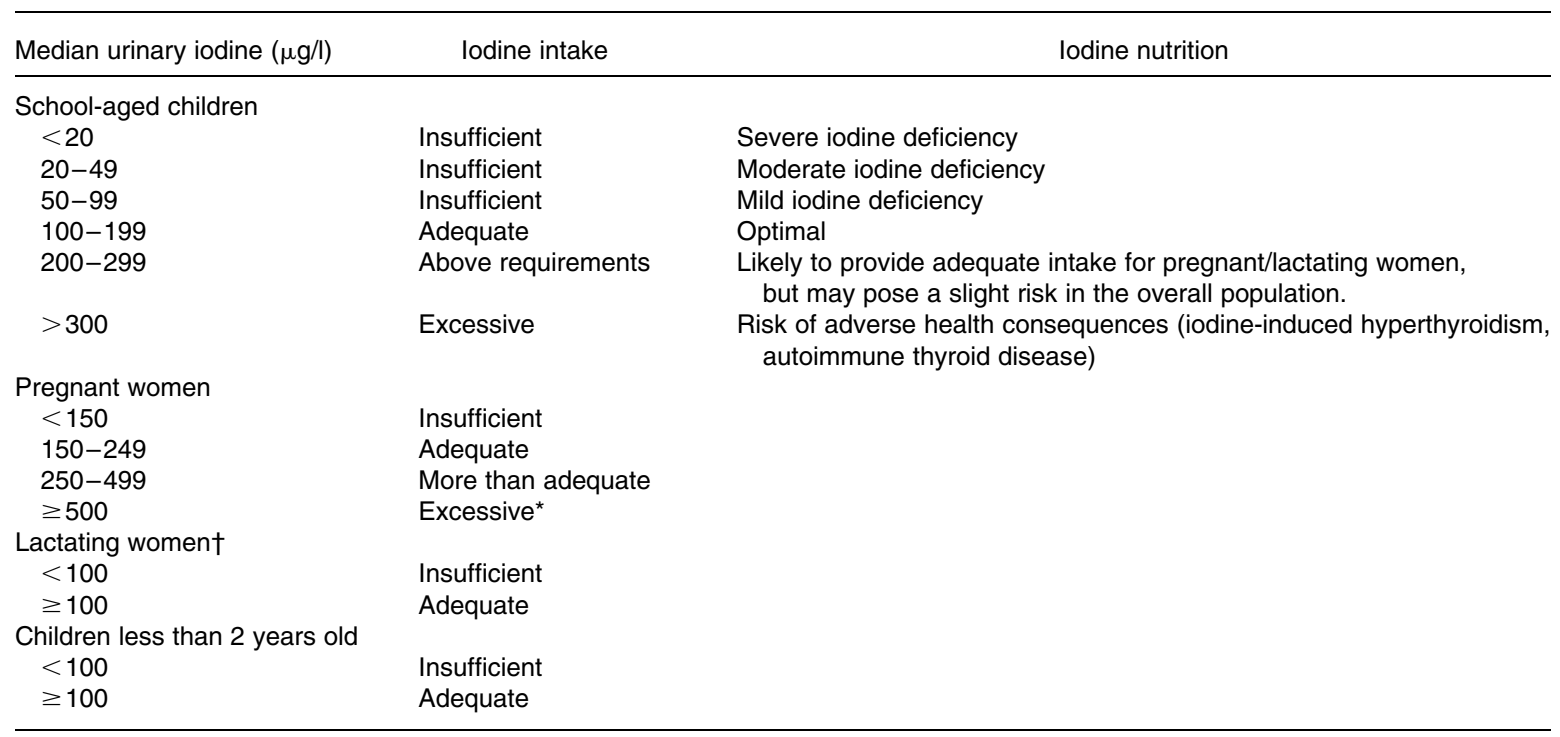

*The term 'excessive' means in excess of the amount required to prevent and control iodine deficiency.

$\dagger$ In lactating women, the figures for median urinary iodine are lower than the iodine requirements because of the iodine excreted in breast milk.

severity of iodine deficiency in populations using the following criteria: $<5 \%$, iodine sufficiency; $5.0 \%-19.9 \%$, mild deficiency; 20.0\%-29.9\%, moderate deficiency; and $>30 \%$, severe deficiency ${ }^{(1)}$ (Table 2).

\section{Urinary iodine concentration}

Because $>90 \%$ of ingested iodine is excreted in the urine, UI is an excellent indicator of recent iodine intake. UI can be expressed as a concentration $(\mu \mathrm{g} / \mathrm{l})$, in relationship to creatinine excretion ( $\mu \mathrm{g}$ iodine/g creatinine), or as 24-hour excretion ( $\mu \mathrm{g} /$ day). For populations, because it is impractical to collect 24 hour samples in field studies, UI can be measured in spot urine specimens from a representative sample of the target group, and expressed as the median, in $\mu \mathrm{g} / \mathrm{l}^{(1)}$. Variations in hydration among individuals generally even out in a large number of samples, so that the median UI in spot samples correlates well with that from 24 hour samples. For national, school-based surveys of iodine nutrition, the median UI from a representative sample of spot urine collections from $\approx 1200$ children ( 30 sampling clusters $\times 40$ children per cluster) can be used to classify a population's iodine status $^{(1)}$ (Table 1).

However, the median UI is often misinterpreted. Individual iodine intakes, and, therefore, spot UI concentrations are highly variable from day-to-day ${ }^{(8)}$, and a common mistake is to assume that all subjects with a spot UI $<100 \mu \mathrm{g} / \mathrm{l}$ are iodine deficient. To estimate iodine intakes in individuals, 24 hour collections are preferable, but difficult to obtain. An alternative is to use the age-and sex adjusted iodine:creatinine ratio in adults, but this also has limitations ${ }^{(9)}$. Creatinine may be unreliable for estimating daily iodine excretion from spot samples, especially in malnourished subjects where creatinine concentration is low. Daily iodine intake for population estimates can be extrapolated from UI, using estimates of mean 24 hour urine volume and assuming an average iodine bioavailability of $92 \%$ using the formula: Urinary iodine $(\mu \mathrm{g} / \mathrm{l}) \times 0.0235 \times$ body weight $(\mathrm{kg})=$ daily iodine intake ${ }^{(10)}$. Using this formula, a median UI of $100 \mu \mathrm{g} / \mathrm{l}$ in an adult corresponds roughly to an average daily intake of $150 \mu \mathrm{g}$.

\section{Thyroid stimulating hormone}

Because serum thyroid stimulating hormone (TSH) is determined mainly by the level of circulating thyroid hormone, which in turn reflects iodine intake, TSH can be used as an indicator of iodine nutrition. However, in older children and adults, although serum TSH may be slightly increased by iodine deficiency, values often remain within the normal range. TSH is therefore a relatively insensitive indicator of iodine nutrition in adults ${ }^{(1)}$. In contrast, TSH is a sensitive indicator of iodine status in the newborn period ${ }^{(11,12)}$. Compared to the adult, the newborn thyroid contains less iodine but has higher rates of iodine turnover. Particularly when iodine supply is low, maintaining high iodine turnover requires increased TSH stimulation. Serum TSH concentrations are therefore increased in iodine deficient infants for the first few weeks of life, a condition termed transient newborn hypothyroidism. In areas of iodine deficiency, an increase in transient newborn hypothyroidism, indicated by $>3 \%$ of newborn TSH values above the threshold of $5 \mathrm{mU} / 1$ whole blood collected 3 to 4 days after birth, suggests iodine deficiency in the population $^{(12)}$. TSH is used in many countries for routine newborn screening to detect congenital hypothyroidism. If already in place, such screening offers a sensitive indicator of iodine nutrition. Newborn TSH is an important measure because it reflects iodine status during a period when the developing brain is particularly sensitive to iodine deficiency.

\section{Thyroglobulin}

Thyroglobulin ( $\mathrm{Tg}$ ) is synthesized only in the thyroid, and is the most abundant intrathyroidal protein. In iodine sufficiency, 
Table 2. Indicators of iodine status at population level (WHO/UNICEF/ICCIDD, 2007)

\begin{tabular}{|c|c|c|c|c|}
\hline Indicator (units) & Age group & Advantages & Disadvantages & Application \\
\hline $\begin{array}{l}\text { Median urinary iodine } \\
\text { concentration }(\mu \mathrm{g} / \mathrm{l})\end{array}$ & $\begin{array}{l}\text { School-age children, } \\
\text { adults and pregnant } \\
\text { women }\end{array}$ & $\begin{array}{l}\text { Spot urine samples are } \\
\text { easy to obtain } \\
\text { Relatively low cost } \\
\text { External quality control } \\
\text { program in place }\end{array}$ & $\begin{array}{l}\text { Not useful for individual } \\
\text { assessment } \\
\text { Assesses iodine intake only } \\
\text { over the past few days } \\
\text { Meticulous laboratory practice } \\
\text { needed to avoid contamination } \\
\text { Sufficiently large number of } \\
\text { samples needed to allow for } \\
\text { varying degrees of subject } \\
\text { hydration }\end{array}$ & See Table 1 \\
\hline $\begin{array}{l}\text { Goitre rate by } \\
\text { palpation (\%) }\end{array}$ & $\begin{array}{l}\text { School-age } \\
\text { children }\end{array}$ & $\begin{array}{l}\text { Simple and rapid screening } \\
\text { test } \\
\text { Requires no specialized } \\
\text { equipment }\end{array}$ & $\begin{array}{l}\text { Specificity and sensitivity are low } \\
\text { due to a high inter-observer vari- } \\
\text { ation } \\
\text { Responds only slowly to changes } \\
\text { in iodine intake }\end{array}$ & $\begin{array}{l}\text { Degree of IDD by goitre rate: } \\
\text { 0-4.9\% - None } \\
5-19.9 \% \text { - Mild } \\
20-29.9 \% \text { - Moderate } \\
\geq 30 \% \text { - Severe }\end{array}$ \\
\hline $\begin{array}{l}\text { Goitre rate by } \\
\text { ultrasound (\%) }\end{array}$ & $\begin{array}{l}\text { School-age } \\
\text { children }\end{array}$ & $\begin{array}{l}\text { More precise than palpation } \\
\text { Reference values estab- } \\
\text { lished as a function of } \\
\text { age, sex, and body } \\
\text { surface area }\end{array}$ & $\begin{array}{l}\text { Requires expensive equipment } \\
\text { and electricity } \\
\text { Operator needs special training } \\
\text { Responds only slowly to changes } \\
\text { in iodine intake }\end{array}$ & \\
\hline $\begin{array}{l}\text { Thyroid stimulating } \\
\text { hormone }(\mathrm{mU} / \mathrm{l})\end{array}$ & Newborns & $\begin{array}{l}\text { Measures thyroid function at } \\
\text { a particularly vulnerable } \\
\text { age } \\
\text { Minimal costs if a congenital } \\
\text { hypothyroidism screening } \\
\text { program is already in } \\
\text { place } \\
\text { Collection by heel stick and } \\
\text { storage on filter paper is } \\
\text { simple }\end{array}$ & $\begin{array}{l}\text { Not useful if iodine antiseptics used } \\
\text { during delivery } \\
\text { Requires a standardized, sensitive } \\
\text { assay } \\
\text { Should be taken by heel-prick at } \\
\text { least } 48 \text { hours after birth to avoid } \\
\text { physiological newborn surge }\end{array}$ & $\begin{array}{l}\text { A }<3 \% \text { frequency of TSH } \\
\text { values }>5 \mathrm{mU} / \mathrm{l} \text { indicates } \\
\text { iodine sufficiency in a } \\
\text { population }\end{array}$ \\
\hline $\begin{array}{l}\text { Serum or whole blood } \\
\text { thyroglobulin }(\mu \mathrm{g} / \mathrm{l})\end{array}$ & $\begin{array}{l}\text { School-age children } \\
\text { and adults }\end{array}$ & $\begin{array}{l}\text { Collection by finger stick } \\
\text { and storage on filter } \\
\text { paper is simple } \\
\text { International reference } \\
\text { range available } \\
\text { Measures improving thyroid } \\
\text { function within several } \\
\text { months after iodine } \\
\text { repletion }\end{array}$ & $\begin{array}{l}\text { Expensive immunoassay } \\
\text { Standard reference material is } \\
\text { available, but needs validation }\end{array}$ & $\begin{array}{l}\text { Reference interval in iodine- } \\
\text { sufficient children is } \\
4-40 \mu \mathrm{g} / \mathrm{l}\end{array}$ \\
\hline
\end{tabular}

small amounts of $\mathrm{Tg}$ are secreted into the circulation, and serum $\mathrm{Tg}$ is normally $<10 \mu \mathrm{g} / \mathrm{l}^{(13)}$. In areas of endemic goitre, serum $\mathrm{Tg}$ increases due to greater thyroid cell mass and TSH stimulation. Serum $\mathrm{Tg}$ is well correlated with the severity of iodine deficiency as measured by $\mathrm{UI}^{(14)}$. Intervention studies examining the potential of $\mathrm{Tg}$ as an indicator of response to iodized oil and potassium iodide have shown that $\mathrm{Tg}$ falls rapidly with iodine repletion, and that $\mathrm{Tg}$ is a more sensitive indicator of iodine repletion than TSH or $\mathrm{T} 4^{(15,16)}$. However, commercially-available assays measure serum $\mathrm{Tg}$, which requires venipuncture, centrifugation and frozen sample transport, which may be difficult in remote areas.

A new assay for $\mathrm{Tg}$ has been developed for dried blood spots taken by a finger prick ${ }^{(17,18)}$, simplifying collection and transport. In prospective studies, dried blood spot $\mathrm{Tg}$ has been shown to be a sensitive measure of iodine status and reflects improved thyroid function within several months after iodine repletion ${ }^{(17,18)}$. However, several questions need to be resolved before $\mathrm{Tg}$ can be widely adopted as an indicator of iodine status. One question is the need for concurrent measurement of anti-Tg antibodies to avoid potential underestimation of $\mathrm{Tg}$; it is unclear how prevalent anti-Tg antibodies are in iodine deficiency, or whether they are precipitated by iodine prophylaxis ${ }^{(19,20)}$. Another limitation is large interassay variability and poor reproducibility, even with the use of standardization ${ }^{(13)}$. This has made it difficult to establish normal ranges and/or cutoffs to distinguish severity of iodine deficiency. However, recently an international reference range and a reference standard for DBS $\mathrm{Tg}$ in iodine-sufficient school children $(4-40 \mu \mathrm{g} / \mathrm{l})$ has been made available ${ }^{(17)}$ (Table 2).

\section{Thyroid hormone concentrations}

In contrast, thyroid hormone concentrations are poor indicators of iodine status. In iodine-deficient populations, serum T3 increases or remains unchanged, and serum T4 usually decreases. However, these changes are often within the normal range, and the overlap with iodine-sufficient populations is large enough to make thyroid hormone levels an insensitive measure of iodine nutrition ${ }^{(1)}$. 
Iron

Definitions of iron deficiency states

1. Iron deficiency $(I D)$ is a reduction in body $\mathrm{Fe}$ to the extent that cellular storage $\mathrm{Fe}$ required for metabolic/ physiological functions is fully exhausted, with or without anaemia.

2. Iron deficiency anaemia (IDA) is defined as ID and a low haemoglobin $(\mathrm{Hb})$.

3. Iron-deficient erythropoiesis (IDE) is defined as laboratory evidence of a reduced supply of circulating $\mathrm{Fe}$ for erythropoesis, indicated by either reduced $\mathrm{Fe}$ saturation of plasma transferrin or signs of ID in circulating erythrocytes. IDE is not synonymous with ID or IDA; IDE can occur despite normal or even increased storage $\mathrm{Fe}$, due to impaired release of Fe to the plasma ${ }^{(21)}$. IDE is often associated with malignancy or inflammation.

\section{Bone-marrow biopsy}

Bone-marrow examination to establish the absence of stainable iron remains the gold standard for the diagnosis of iron deficiency, particularly when performed and reviewed under standardized conditions by experienced investigators. However, marrow examinations are expensive, uncomfortable, and require technical expertise, and are not performed routinely in clinical practice.

\section{Haemoglobin}

Haemoglobin $(\mathrm{Hb})$ is a widely used screening test for ID, but used alone has low specificity and sensitivity. Its sensitivity is low because individuals with baseline $\mathrm{Hb}$ values in the upper range of normal need to lose $20-30 \%$ of their body Fe before their $\mathrm{Hb}$ falls below the cut-off for anaemia ${ }^{(21)}$. Its specificity is low because there are many causes of anaemia other than ID. Cut-off criteria differ with the age and sex of the individual (Table 3), between laboratories, and there are ethnic differences in normal $\mathrm{Hb}^{(22,23)}$.

\section{Mean corpuscular volume and reticulocyte $\mathrm{Hb}$ content}

Measured on widely-available automated haematology analysers, the mean corpuscular volume (MCV) is a reliable, but relatively late indicator of ID, and its differential diagnosis includes thalassemia. The reticulocyte $\mathrm{Hb}$ content $(\mathrm{CHr})$ has been proposed as a sensitive indicator that falls within days of the onset of $\operatorname{IDE}^{(24)}$. However, false normal values can occur when the MCV is increased or in thalassemia; its wide use is limited as it can only be measured on one model of analyzer. For both $\mathrm{MCV}$ and $\mathrm{CHr}$, low specificity limits their clinical utility ${ }^{(25)}$.

\section{Erythrocyte zinc protoporphyrin}

Erythrocyte zinc protoporphyrin (ZnPP) increases in IDE because zinc replaces the missing $\mathrm{Fe}$ during formation of the protoporphyrin ring $^{(26)}$. The ratio of $\mathrm{ZnPP} / \mathrm{haem}$ can be measured directly on a drop of blood using a portable
Table 3. Haemoglobin and haematocrit levels by age and gender below which anaemia is present ${ }^{\star}(\mathrm{WHO}, 2001)$

\begin{tabular}{lcc}
\hline Age or gender group & Haemoglobin $(\mathrm{g} / \mathrm{l})$ & Haematocrit $(\mathrm{l} / \mathrm{l})$ \\
\hline 6 mo-59 mo & 110 & 0.33 \\
$5-11$ y & 115 & 0.34 \\
$12-14$ y & 120 & 0.36 \\
Nonpregnant women & 120 & 0.36 \\
Pregnant women & 110 & 0.33 \\
Men $>15 y$ & 130 & 0.39 \\
\hline
\end{tabular}

${ }^{*}$ At altitudes $<1000 \mathrm{~m}$.

hematofluorometer. In adults, ZnPP has a high sensitivity in diagnosing iron deficiency ${ }^{(27-32)}$. In infants and children, ZnPP may also be a sensitive test for detecting iron deficiency ${ }^{(33-36)}$. However, the specificity of ZnPP in identifying iron deficiency may be limited, because $\mathrm{ZnPP}$ can be increased by lead poisoning, anaemia of chronic disease, chronic infections and inflammation, haemolytic anaemias, or haemoglobinopathies ${ }^{(29,37-40)}$. The effect of malaria on $\mathrm{ZnPP}$ in children is equivocal ${ }^{(41-43)}$.

Direct comparisons between studies of $\mathrm{ZnPP}$ are difficult because of interassay variation. Interfering substances in plasma produced by acute inflammation and haemolysis can increase ZnPP concentrations 3-4-fold in the absence of iron deficiency ${ }^{(28)}$. These interfering substances can be removed by washing the erythrocytes, which markedly improves assay specificity ${ }^{(28,44)}$; however, this procedure is not always done because it is time-consuming. Another problem with $\mathrm{ZnPP}$ is that results can be expressed as a concentration (free erythrocyte protoporphyrin, EP, or ZnPP, and these are not interchangeable) or as the ZnPP-haem molar ratio; the latter is recommended ${ }^{(45)}$. Several cut-offs have been proposed for ZnPP to define iron deficiency ${ }^{(28,32,38,46,47)}$. Using a haematofluorometer on washed erythrocytes, Hastka et al. ${ }^{(28)}$ recommended a cutoff of $>40 \mu \mathrm{mol} / \mathrm{mol}$ haem on the basis of studies in healthy adults. In contrast, other authors, using unwashed erythrocytes, have proposed a cutoff of $>80 \mu \mathrm{mol}$ to indicate iron deficiency ${ }^{(46,47)}$. ZnPP is a useful screening test in field surveys, particularly in children, where uncomplicated ID is the primary cause of anaemia. Because of the difficulty in automating the assay, ZPP has been not widely adopted by clinical laboratories.

\section{Transferrin saturation}

Transferrin saturation is a widely used screening test for ID, calculated as the ratio of plasma $\mathrm{Fe}$ to total Fe-binding capacity. Although relatively inexpensive, its use is limited by diurnal variation in serum $\mathrm{Fe}$ and the many clinical disorders that influence transferrin levels ${ }^{(21)}$.

\section{Serum ferritin}

Serum ferritin (SF) may be the most useful laboratory measure of Fe status; a low value is diagnostic of IDA in a patient with anaemia (Table 4). In healthy individuals, SF is directly proportional to $\mathrm{Fe}$ stores: $1 \mu \mathrm{g} / \mathrm{l} \mathrm{SF}$ corresponds to $8-10 \mathrm{mg}$ body $\mathrm{Fe}$ or $120 \mu \mathrm{g}$ storage $\mathrm{Fe} / \mathrm{kg}$ body weight ${ }^{(21)}$. It is widely available, well-standardized, and has repeatedly been 
Table 4. Iron status on the basis of serum ferritin concentrations $(\mu \mathrm{g} / \mathrm{l})$ (WHO, 2001)

\begin{tabular}{|c|c|c|c|c|}
\hline \multirow[b]{2}{*}{ Iron status } & \multicolumn{2}{|c|}{$<5 y$} & \multicolumn{2}{|c|}{$\geq 5 y$} \\
\hline & Male & Female & Male & Female \\
\hline Depleted iron stores & $<12$ & $<12$ & $<15$ & $<15$ \\
\hline $\begin{array}{l}\text { Depleted iron stores } \\
\text { in the presence of } \\
\text { infection }\end{array}$ & $<30$ & $<30$ & - & - \\
\hline Risk of iron overload & - & - & $>200$ (adult) & $>150$ (adult) \\
\hline
\end{tabular}

demonstrated to be superior to other measurements for identifying IDA. In a pooled analysis of 2579 subjects using receiver-operator characteristic curves, the mean area-underthe-curve for serum ferritin was $0.95,0.77$ for the ZPP, 0.76 for the MCV and 0.74 for transferrin saturation ${ }^{(48)}$. In a pooled analysis of 9 randomized iron intervention trials ferritin shows a larger and more consistent response to iron interventions than ZPP or $\mathrm{TfR}^{(49)}$. However, because it is an acute phase protein, $\mathrm{SF}$ is increased independent of $\mathrm{Fe}$ status by acute or chronic inflammation. It is also unreliable in the setting of malignancy, hyperthyroidism, liver disease, and heavy alcohol intake.

\section{Serum transferrin receptor}

The serum transferrin receptor (TfR) is a transmembrane glycoprotein that transfers circulating $\mathrm{Fe}$ into developing red cells; $\approx 80 \%$ of TfR in the body are found on erythroid precursors. A circulating, soluble form of TfR consists of the extracellular domain of the receptor. The total mass of cellular TfR and, therefore, of serum TfR depends both on the number of erythroid precursors in the bone marrow and on the number of TfRs per cell, a function of the iron status of the cell ${ }^{(50,51)}$. Serum TfR concentration appears to be a specific indicator of IDE that is not confounded by inflammation $^{(52)}$. However, normal expansion of the erythroid mass during growth ${ }^{(53-55)}$, as well as diseases common in developing countries, including thalassemia, megaloblastic anaemia due to folate deficiency, or hemolysis due to malaria, may increase erythropoiesis and TfR independent of iron status ${ }^{(56-58)}$. Thus, the diagnostic value of TfR for IDA is uncertain in children from regions where inflammatory conditions, infection and malaria are endemic ${ }^{(59-61)}$. The wider application of TfR has been limited by the high cost of commercial assays. Age-related data for $\mathrm{TfR}$ in children are scarce ${ }^{(62-64)}$, and direct comparison of values obtained with different assays is difficult because of the lack of an international standard. A comparison of the analytical performance of an automated immunoturbidimetric assay with two manual ELISA assays found good correlations $(r>0 \cdot 8)$; however, TfR values by the immunoturbidimetric assay were on average $30 \%$ lower $^{(65)}$.

\section{TfR/SF ratio}

The ratio of $\mathrm{TfR} / \mathrm{SF}$ can be used to quantitatively estimate total body $\mathrm{Fe}^{(66)}$. The logarithm of this ratio is directly proportional to the amount of stored Fe in Fe-replete subjects and the tissue Fe deficit in ID (Table 5). In elderly subjects, the ratio may be more sensitive than other laboratory tests for $\mathrm{ID}^{(67)}$. However, it cannot be used in individuals with inflammation because the SF may be elevated independent of $\mathrm{Fe}$ stores, and is assay specific. In a recent analysis of pooled data from iron intervention studies, calculation of body iron from the TfR/SF ratio showed no clear advantage over SF alone ${ }^{(49)}$. Although only validated for adults, the ratio has also been used in children ${ }^{(68,69)}$. Because TfR assays are currently not standardized, this affects the use of the TfR/SF ratio to estimate body iron; the most common used logarithm is assay specific.

\section{Assessing iron status using multiple indices}

The major diagnostic challenge is to distinguish between IDA in otherwise healthy individuals, and the anaemia of chronic disease (ACD). Inflammatory disorders increase circulating hepcidin levels and hepcidin blocks Fe release from enterocytes and the reticuloendothelial system, resulting in $\operatorname{IDE}^{(70)}$. This can occur despite adequate iron stores. If chronic, inflammation can produce ACD. The distinction between ACD and IDA is difficult, as an elevated SF in anaemia does not exclude IDA in the presence of inflammation. A widely-used marker of inflammation is the C-reactive protein (CRP), but the degree of CRP elevation that invalidates the use of SF to diagnose ID is uncertain; CRP values $>10-30 \mathrm{mg} / \mathrm{l}$ have been used. Moreover, during the acute phase response, the increase in CRP is typically of shorter duration than the increase in SF. Alternate markers, such as alpha $_{1}$-acid glycoprotein (AGP), may be useful, as AGP levels tend to increase later in infection than CRP, and remain elevated for several weeks. If anaemia is present and the CRP is elevated, IDA can usually be diagnosed in individuals with inflammatory disorders/anaemia of chronic disease by an elevated TfR and/or $\mathrm{ZnPP}^{(21,41)}$. Although studies in adults have suggested that elevations in $\operatorname{TfR}^{(52)}$ or in $\mathrm{ZnPP}^{(28)}$ can be a definitive indicator of iron deficiency, a recent study in African children found there was large overlap in the distributions of these indicators in a comparison of children with IDA with those with normal iron status $^{(71)}$. This overlap may be explained by a greater variability in the erythroid mass in children than in adults, together with the many variables affecting children in developing countries that influence TfR and ZnPP independent of iron status, as detailed above. Because of this overlap, the sensitivity and specificity of TfR and ZnPP in identifying iron deficiency and IDA in children will be modest, regardless of the diagnostic cutoffs chosen. Because each test of iron status has limitations in terms of its sensitivity and specificity, they have been combined in models to define iron deficiency. Examples include the model based on low transferrin saturation and high $\mathrm{ZnPP}$, and the ferritin model based on low SF and transferrin saturation and high ZnPP. With these models, specificity increases but sensitivity is low, and they tend to underestimate $\operatorname{ID}^{(47)}$. When it is feasible to measure several indices, the best combination is usually $\mathrm{Hb}, \mathrm{SF}$ and, if CRP is elevated, TfR and/or ZnPP. 
Table 5. The main biochemical indicators of iron deficiency

\begin{tabular}{|c|c|c|c|c|}
\hline & Unit & Commonly used methods & $\begin{array}{l}\text { Threshold indicating } \\
\text { iron deficiency }\end{array}$ & Comments \\
\hline Haemoglobin & $g / l$ & $\begin{array}{l}\text { Cyanmeta using colorimeter or } \\
\text { spectrophotometer or azide- } \\
\text { methhaemoglobin using e.g. } \\
\text { HemoCue }{ }^{\circledR}\end{array}$ & See Table 3 & $\begin{array}{l}\text { Used alone, has low specificity } \\
\text { and sensitivity } \\
\text { Thresholds vary by age, gender, } \\
\text { pregnancy, altitude, ethnicity }\end{array}$ \\
\hline Haematocrit & Decimal ratio or $\%$ & $\begin{array}{l}\text { Centrifugation in capillary tube } \\
\text { or automated flow cytometry }\end{array}$ & See Table 3 & Same as haemoglobin \\
\hline $\begin{array}{l}\text { Blood mean corpuscular } \\
\text { volume (MCV) }\end{array}$ & $\mathrm{fl}\left(10^{-12}\right)$ & $\begin{array}{l}\text { Calculated from the haematocrit } \\
\text { and RBC count or automated } \\
\text { flow cytometry }\end{array}$ & $\begin{array}{l}\text { In older children and } \\
\text { adults; }<82 \mathrm{fl}\end{array}$ & $\begin{array}{l}\text { A reliable, but relatively late } \\
\text { indicator of ID } \\
\text { Low values can also be due to } \\
\text { thalassemia and/or inflam- } \\
\text { mation }\end{array}$ \\
\hline $\begin{array}{l}\text { Blood reticulocyte } \mathrm{Hb} \\
\text { concentration }\end{array}$ & g/l reticulocytes & Automated flow cytometry & $\begin{array}{l}\text { In infants and young } \\
\text { children; }<27.5 \\
\text { In adults; } \leq 28.0\end{array}$ & $\begin{array}{l}\text { A sensitive indicator that falls } \\
\text { within days of onset of IDE } \\
\text { False normal values can occur } \\
\text { when MCV is increased and } \\
\text { in thalassemia }\end{array}$ \\
\hline Serum or plasma iron & $\mu \mathrm{g} / \mathrm{dl}$ & $\begin{array}{l}\text { Colorimetry (sample from } \\
\text { non-EDTA tube) }\end{array}$ & $<40-50$ & $\begin{array}{l}\text { Varies diurnally and after meals } \\
\text { Low values in chronic disease }\end{array}$ \\
\hline $\begin{array}{l}\text { Whole blood zinc } \\
\text { protoporphyrin }\end{array}$ & $\mu \mathrm{mol} / \mathrm{mol}$ of heme & $\begin{array}{l}\text { Fluorescence spectropho- } \\
\text { tometry or portable Aviv } \\
\text { haematofluorimeter }\end{array}$ & $\begin{array}{l}\text { On washed erythrocytes } \\
\text { in children } \geq 5 \text { y and } \\
\text { adults; }>40\end{array}$ & $\begin{array}{l}\text { A useful screening test in field } \\
\text { surveys, particularly in children, } \\
\text { where uncomplicated ID is the } \\
\text { primary cause of anaemia } \\
\text { Red cells should be washed } \\
\text { before measurement because } \\
\text { circulating factors, including } \\
\text { serum bilirubin, can spuri- } \\
\text { ously increase values }\end{array}$ \\
\hline & & & $\begin{array}{l}\text { On unwashed erythrocytes } \\
\text { in children }<5 \mathrm{y} ;>61 \\
\text { in children } \geq 5 \mathrm{y} \text { and } \\
\text { adults; }>70\end{array}$ & $\begin{array}{l}\text { Lead poisoning can elevate } \\
\text { values, particularly in urban/ } \\
\text { industrial settings }\end{array}$ \\
\hline Serum or plasma ferritin & $\mu \mathrm{g} / \mathrm{l}$ & $\begin{array}{l}\text { Immunoassay or } \\
\text { immunoturbidometry }\end{array}$ & See Table 4 & $\begin{array}{l}\text { Probably the most useful labo- } \\
\text { ratory measure of Fe status; } \\
\text { a low value is diagnostic of } \\
\text { IDA in a patient with anaemia } \\
\text { As an acute phase protein, SF is } \\
\text { increased independent of Fe } \\
\text { status by acute or chronic } \\
\text { inflammation; also unreliable } \\
\text { in subjects with malignancy, } \\
\text { hyperthyroidism, liver disease, } \\
\text { or heavy alcohol intake }\end{array}$ \\
\hline $\begin{array}{l}\text { Serum or plasma total } \\
\text { iron binding capacity }\end{array}$ & $\mu \mathrm{g} / \mathrm{dl}$ & $\begin{array}{l}\text { Colorimetric assay of amount } \\
\text { of iron that can be bound to } \\
\text { unsaturated transferrin } \\
\text { in vitro; determination from } \\
\text { transferrin concentration } \\
\text { measured immunologically }\end{array}$ & $>400$ & $\begin{array}{l}\text { Large overlap between normal } \\
\text { values and values in ID }\end{array}$ \\
\hline $\begin{array}{l}\text { Serum or plasma trans- } \\
\text { ferrin saturation }\end{array}$ & $\%$ & $\begin{array}{l}\text { Calculated from: Serum } \\
\text { iron/TIBC }\end{array}$ & $<15 \%$ & Same as for serum iron \\
\hline $\begin{array}{l}\text { Serum or plasma trans- } \\
\text { ferrin receptor }\end{array}$ & $\mathrm{mg} / \mathrm{l}$ & $\begin{array}{l}\text { Immunoassay or immuno- } \\
\text { turbidometry }\end{array}$ & Varies with assay & $\begin{array}{l}\text { Also increased by conditions } \\
\text { with enhanced erythropoesis } \\
\text { Not significantly affected by the } \\
\text { acute phase response, but } \\
\text { may be influenced by malaria, } \\
\text { age and ethnicity }\end{array}$ \\
\hline Body iron stores & $\mathrm{mg} / \mathrm{kg}$ body weight & $\begin{array}{l}\text { Ratio of transferrin receptor to } \\
\text { ferritin : [log (TfR/ferritin } \\
\text { ratio) }-2 \cdot 8229] / 0 \cdot 1207\end{array}$ & $\begin{array}{l}\text { Negative values indicate } \\
\text { tissue iron deficit }\end{array}$ & $\begin{array}{l}\text { Cannot be used in individuals } \\
\text { with inflammation because } \\
\text { the SF may be elevated } \\
\text { independent of Fe stores } \\
\text { Is assay specific } \\
\text { Although only validated for } \\
\text { adults, is often used in children }\end{array}$ \\
\hline
\end{tabular}

* Using RAMCO ${ }^{\circledast}$ ELISA for transferrin receptor. 


\section{References}

1. WHO/UNICEF/ICCIDD (2007) Assessment of Iodine Deficiency Disorders and Monitoring their Elimination, 2nd ed. Geneva: World Health Organization.

2. Zimmermann M, Saad A, Hess S, Torresani T \& Chaouki N (2000) Thyroid ultrasound compared with World Health Organization 1960 and 1994 palpation criteria for determination of goiter prevalence in regions of mild and severe iodine deficiency. Eur $J$ Endocrinol 143, 727-731.

3. Zimmermann MB, Hess SY, Molinari L, et al. (2004) New reference values for thyroid volume by ultrasound in iodine-sufficient schoolchildren: a World Health Organization/ Nutrition for Health and Development Iodine Deficiency Study Group Report. Am J Clin Nutr 79, 231-237.

4. Brunn J, Block U, Ruf G, Bos I, Kunze WP \& Scriba PC (1981) Volumetric analysis of thyroid lobes by real-time ultrasound (author's transl). Dtsch Med Wochenschr 106, 1338-1340.

5. Zimmermann MB, Molinari L, Spehl M, Weidinger-Toth J, Podoba J, Hess S \& Delange F (2001) Toward a consensus on reference values for thyroid volume in iodine-replete schoolchildren: results of a workshop on inter-observer and interequipment variation in sonographic measurement of thyroid volume. Eur J Endocrinol 144, 213-220.

6. Aghini-Lombardi F, Antonangeli L, Pinchera A, Leoli F, Rago T, Bartolomei AM \& Vitti P (1997) Effect of iodized salt on thyroid volume of children living in an area previously characterized by moderate iodine deficiency. J Clin Endocrinol Metab 82, 1136-1139.

7. Zimmermann MB, Hess SY, Adou P, Toresanni T, Wegmuller R \& Hurrell RF (2003) Thyroid size and goiter prevalence after introduction of iodized salt: a 5-y prospective study in schoolchildren in Cote d'Ivoire. Am J Clin Nutr 77, 663-667.

8. Andersen S, Karmisholt J, Pedersen KM \& Laurberg P (2008) Reliability of studies of iodine intake and recommendations for number of samples in groups and in individuals. $\mathrm{Br} \mathrm{J} \mathrm{Nutr}$ 99, 813-818.

9. Knudsen N, Christiansen E, Brandt-Christensen M, Nygaard B \& Perrild H (2000) Age- and sex-adjusted iodine/creatinine ratio. A new standard in epidemiological surveys? Evaluation of three different estimates of iodine excretion based on casual urine samples and comparison to $24 \mathrm{~h}$ values. Eur $J$ Clin Nutr 54, 361-363.

10. Institute of Medicine (2001) Dietary Reference Intakes for Vitamin A, Vitamin K, Arsenic, Boron, Chromium, Copper, Iodine, Iron, Manganese, Molybdenum, Nickel, Silicon, Vanadium, and Zinc. Washington, DC: National Academy Press.

11. Delange F (1997) Neonatal screening for congenital hypothyroidism: results and perspectives. Horm Res 48, 51-61.

12. Zimmermann MB, Aeberli I, Torresani T \& Burgi H (2005) Increasing the iodine concentration in the Swiss iodized salt program markedly improved iodine status in pregnant women and children: a 5-y prospective national study. Am J Clin Nutr 82, 388-392.

13. Spencer CA \& Wang CC (1995) Thyroglobulin measurement. Techniques, clinical benefits, and pitfalls. Endocrinol Metab Clin North Am 24, 841-863.

14. Knudsen N, Bulow I, Jorgensen T, Perrild H, Ovesen L \& Laurberg P (2001) Serum Tg - a sensitive marker of thyroid abnormalities and iodine deficiency in epidemiological studies J Clin Endocrinol Metab 86, 3599-3603

15. Benmiloud M, Chaouki ML, Gutekunst R, Teichert HM, Wood WG \& Dunn JT (1994) Oral iodized oil for correcting iodine deficiency: optimal dosing and outcome indicator selection. $J$ Clin Endocrinol Metab 79, 20-24.

16. Missler U, Gutekunst R \& Wood WG (1994) Thyroglobulin is a more sensitive indicator of iodine deficiency than thyrotropin: development and evaluation of dry blood spot assays for thyrotropin and thyroglobulin in iodine-deficient geographical areas. Eur J Clin Chem Clin Biochem 32, 137-143.

17. Zimmermann MB, de Benoist B, Corigliano S, et al. (2006) Assessment of iodine status using dried blood spot thyroglobulin: development of reference material and establishment of an international reference range in iodine-sufficient children. $J$ Clin Endocrinol Metab 91, 4881-4887.

18. Zimmermann MB, Moretti D, Chaouki N \& Torresani T (2003) Development of a dried whole-blood spot thyroglobulin assay and its evaluation as an indicator of thyroid status in goitrous children receiving iodized salt. Am J Clin Nutr 77, $1453-1458$.

19. Loviselli A, Velluzzi F, Mossa P, et al. (2001) The Sardinian Autoimmunity Study:3. Studies on circulating antithyroid antibodies in Sardinian schoolchildren: relationship to goiter prevalence and thyroid function. Thyroid 11, 849-857.

20. Zimmermann MB, Moretti D, Chaouki N \& Torresani T (2003) Introduction of iodized salt to severely iodine-deficient children does not provoke thyroid autoimmunity: a one-year prospective trial in northern Morocco. Thyroid 13, 199-203.

21. Cook JD (2005) Diagnosis and management of iron-deficiency anaemia. Best Pract Res Clin Haematol 18, 319-332.

22. Himes JH, Walker SP, Williams S, Bennett F \& GranthamMcGregor SM (1997) A method to estimate prevalence of iron deficiency and iron deficiency anemia in adolescent Jamaican girls. Am J Clin Nutr 65, 831-836.

23. Johnson-Spear MA \& Yip R (1994) Hemoglobin difference between black and white women with comparable iron status: justification for race-specific anemia criteria. Am J Clin Nutr 60, $117-121$

24. Mast AE, Blinder MA, Lu Q, Flax S \& Dietzen DJ (2002) Clinical utility of the reticulocyte hemoglobin content in the diagnosis of iron deficiency. Blood 99, 1489-1491.

25. Thomas C \& Thomas L (2002) Biochemical markers and hematologic indices in the diagnosis of functional iron deficiency. Clin Chem 48, 1066-1076.

26. Metzgeroth G, Adelberger V, Dorn-Beineke A, Kuhn C, Schatz M, Maywald O, Bertsch T, Wisser H, Hehlmann R \& Hastka J (2005) Soluble transferrin receptor and zinc protoporphyrin - competitors or efficient partners? Eur J Haematol 75, 309-317.

27. Hastka J, Lasserre JJ, Schwarzbeck A \& Hehlmann R (1994) Central role of zinc protoporphyrin in staging iron deficiency. Clin Chem 40, 768-773.

28. Hastka J, Lasserre JJ, Schwarzbeck A, Strauch M \& Hehlmann R (1992) Washing erythrocytes to remove interferents in measurements of zinc protoporphyrin by front-face hematofluorometry. Clin Chem 38, 2184-2189.

29. Labbe RF \& Dewanji A (2004) Iron assessment tests: transferrin receptor vis-a-vis zinc protoporphyrin. Clin Biochem 37, $165-174$.

30. Labbe RF, Dewanji A \& McLaughlin K (1999) Observations on the zinc protoporphyrin/heme ratio in whole blood. Clin Chem 45, 146-148.

31. Piomelli S (1987) The diagnostic utility of measurements of erythrocyte porphyrins. Hematol Oncol Clin North Am 1, 419-430.

32. Wong SS, Qutishat AS, Lange J, Gornet TG \& Buja LM (1996) Detection of iron-deficiency anemia in hospitalized patients by zinc protoporphyrin. Clin Chim Acta 244, 91-101.

33. Hershko C, Konijn AM, Link G, Moreb J, Grauer F \& Weissenberg E (1985) Combined use of zinc protoporphyrin (ZPP), mean corpuscular volume and haemoglobin measurements for classifying microcytic RBC disorders in children and young adults. Clin Lab Haematol 7, 259-269.

34. Mei Z, Parvanta I, Cogswell ME, Gunter EW \& GrummerStrawn LM (2003) Erythrocyte protoporphyrin or hemoglobin: 
which is a better screening test for iron deficiency in children and women? Am J Clin Nutr 77, 1229-1233.

35. Serdar MA, Sarici SU, Kurt I, Alpay F, Okutan V, Kurnaz L \& Kutluay T (2000) The role of erythrocyte protoporphyrin in the diagnosis of iron deficiency anemia of children. $J$ Trop Pediatr 46, 323-326.

36. Siegel RM \& LaGrone DH (1994) The use of zinc protoporphyrin in screening young children for iron deficiency. Clin Pediatr (Phila) 33, 473-479.

37. Graham EA, Felgenhauer J, Detter JC \& Labbe RF (1996) Elevated zinc protoporphyrin associated with thalassemia trait and hemoglobin E. J Pediatr 129, 105-110.

38. Harthoorn-Lasthuizen EJ, van't Sant P, Lindemans J \& Langenhuijsen MM (2000) Serum transferrin receptor and erythrocyte zinc protoporphyrin in patients with anemia. Clin Chem 46, 719-722.

39. Hastka J, Lasserre JJ, Schwarzbeck A, Strauch M \& Hehlmann R (1993) Zinc protoporphyrin in anemia of chronic disorders. Blood 81, 1200-1204.

40. Pootrakul P, Wattanasaree J, Anuwatanakulchai M \& Wasi $\mathrm{P}$ (1984) Increased red blood cell protoporphyrin in thalassemia: a result of relative iron deficiency. Am J Clin Pathol 82, 289-293.

41. Asobayire FS, Adou P, Davidsson L, Cook JD \& Hurrell RF (2001) Prevalence of iron deficiency with and without concurrent anemia in population groups with high prevalences of malaria and other infections: a study in Cote d'Ivoire. Am J Clin Nutr 74, 776-782.

42. Schneider D, Aplogan A, Dyck JL, Berger J \& Chippaux JP (1993) Determination of erythrocyte protoporphyrin with a hematofluorometer: interference due to malarial parasitaemia. Ann Biol Clin (Paris) 51, 141-142.

43. Stoltzfus RJ, Chwaya HM, Albonico M, Schulze KJ, Savioli L \& Tielsch JM (1997) Serum ferritin, erythrocyte protoporphyrin and hemoglobin are valid indicators of iron status of school children in a malaria-holoendemic population. $J$ Nutr 127, 293-298.

44. Rettmer R, Gunter E \& Labbe R (1987) Overcoming the limitation of hematofluorometry for assaying zinc protoporphyrin. Ann N Y Acad Sci 514, 345-346.

45. NCCLS (1996) Erythrocyte Protoporphyrin Testing: Approval Guideline. Villanova, PA: National Committee on Clinical Laboratory Standards.

46. Labbe RF, Vreman HJ \& Stevenson DK (1999) Zinc protoporphyrin: a metabolite with a mission. Clin Chem 45, 2060-2072.

47. WHO/UNICEF/ICCIDD (2001) Iron Deficiency Anemia: Assessment, Prevention and Control. Geneva: World Health Organisation, WHO/NHD/013.

48. Guyatt $\mathrm{GH}$, Oxman AD, Ali M, Willan A, Mcllroy W \& Patterson C (1992) Laboratory diagnosis of iron-deficiency anemia: an overview. J Gen Intern Med 7, 145-153.

49. Mei Z, Cogswell ME, Parvanta I, Lynch S, Beard JL, Stoltzfus RJ \& Grummer-Strawn LM (2005) Hemoglobin and ferritin are currently the most efficient indicators of population response to iron interventions: an analysis of nine randomized controlled trials. J Nutr 135, 1974-1980.

50. Baillie FJ, Morrison AE \& Fergus I (2003) Soluble transferrin receptor: a discriminating assay for iron deficiency. Clin Lab Haematol 25, 353-357.

51. Beguin Y (2003) Soluble transferrin receptor for the evaluation of erythropoiesis and iron status. Clin Chim Acta 329, 9-22.

52. Skikne BS, Flowers CH \& Cook JD (1990) Serum transferrin receptor: a quantitative measure of tissue iron deficiency. Blood 75, 1870-1876.

53. Kling PJ, Roberts RA \& Widness JA (1998) Plasma transferrin receptor levels and indices of erythropoiesis and iron status in healthy term infants. J Pediatr Hematol Oncol 20, 309-314.
54. Kohgo Y, Niitsu Y, Kondo H, Kato J, Tsushima N, Sasaki K, Hirayama M, Numata T, Nishisato T \& Urushizaki I (1987) Serum transferrin receptor as a new index of erythropoiesis. Blood 70, 1955-1958.

55. Olivares $\mathrm{M}$, Walter $\mathrm{T}$, Cook JD, Hertrampf E \& Pizarro $\mathrm{F}$ (2000) Usefulness of serum transferrin receptor and serum ferritin in diagnosis of iron deficiency in infancy. Am J Clin Nutr 72, 1191-1195.

56. Menendez C, Quinto LL, Kahigwa E, Alvarez L, Fernandez R, Gimenez N, Schellenberg D, Aponte JJ, Tanner M \& Alonso PL (2001) Effect of malaria on soluble transferrin receptor levels in Tanzanian infants. Am J Trop Med Hyg 65, 138-142.

57. Verhoef H, West CE, Ndeto P, Burema J, Beguin Y \& Kok FJ (2001) Serum transferrin receptor concentration indicates increased erythropoiesis in Kenyan children with asymptomatic malaria. Am J Clin Nutr 74, 767-775.

58. Worwood M (2002) Serum transferrin receptor assays and their application. Ann Clin Biochem 39, 221-230.

59. Beesley R, Filteau S, Tomkins A, Doherty T, Ayles H, Reid A, Ellman T \& Parton S (2000) Impact of acute malaria on plasma concentrations of transferrin receptors. Trans $R$ Soc Trop Med Hyg 94, 295-298.

60. Kuvibidila S, Mark JA, Warrier RP, Yu L, Ode D \& Tshefu KA (1995) Soluble transferrin receptor as an index of iron status in Zairian children with malaria. J Trop Med Hyg 98, 373-378.

61. Williams TN, Maitland K, Rees DC, Peto TE, Bowden DK, Weatherall DJ \& Clegg JB (1999) Reduced soluble transferrin receptor concentrations in acute malaria in Vanuatu. Am $J$ Trop Med Hyg 60, 875-878.

62. Anttila R, Cook JD \& Siimes MA (1997) Body iron stores decrease in boys during pubertal development: the transferrin receptor-ferritin ratio as an indicator of iron status. Pediatr Res 41, 224-228.

63. Suominen P, Virtanen A, Lehtonen-Veromaa M, Heinonen OJ, Salmi TT, Alanen M, Mottonen T, Rajamaki A \& Irjala K (2001) Regression-based reference limits for serum transferrin receptor in children 6 months to 16 years of age. Clin Chem 47, 935-937.

64. Virtanen MA, Viinikka LU, Virtanen MK, Svahn JC, Anttila RM, Krusius T, Cook JD, Axelsson IE, Raiha NC \& Siimes MA (1999) Higher concentrations of serum transferrin receptor in children than in adults. Am J Clin Nutr 69, $256-260$

65. Pfeiffer CM, Cook JD, Mei Z, Cogswell ME, Looker AC \& Lacher DA (2007) Evaluation of an automated soluble transferrin receptor (sTfR) assay on the Roche Hitachi analyzer and its comparison to two ELISA assays. Clin Chim Acta 382, 112-116.

66. Cook JD, Flowers CH \& Skikne BS (2003) The quantitative assessment of body iron. Blood 101, 3359-3364.

67. Rimon E, Levy S, Sapir A, Gelzer G, Peled R, Ergas D \& Sthoeger ZM (2002) Diagnosis of iron deficiency anemia in the elderly by transferrin receptor-ferritin index. Arch Intern Med 162, 445-449.

68. Cook JD, Boy E, Flowers C \& Daroca Mdel C (2005) The influence of high-altitude living on body iron. Blood 106, 1441-1446.

69. Zimmermann MB, Wegmueller R, Zeder C, Chaouki N, Rohner F, Saissi M, Torresani T \& Hurrell RF (2004) Dual fortification of salt with iodine and micronized ferric pyrophosphate: a randomized, double-blind, controlled trial. Am J Clin Nutr 80, 952-959.

70. Nemeth E, Rivera S, Gabayan V, Keller C, Taudorf S, Pedersen BK \& Ganz T (2004) IL-6 mediates hypoferremia of inflammation by inducing the synthesis of the iron regulatory hormone hepcidin. J Clin Invest 113, 1271-1276.

71. Zimmermann MB, Molinari L, Staubli-Asobayire F, Hess SY, Chaouki N, Adou P \& Hurrell RF (2005) Serum transferrin receptor and zinc protoporphyrin as indicators of iron status in African children. Am J Clin Nutr 81, 615-623. 